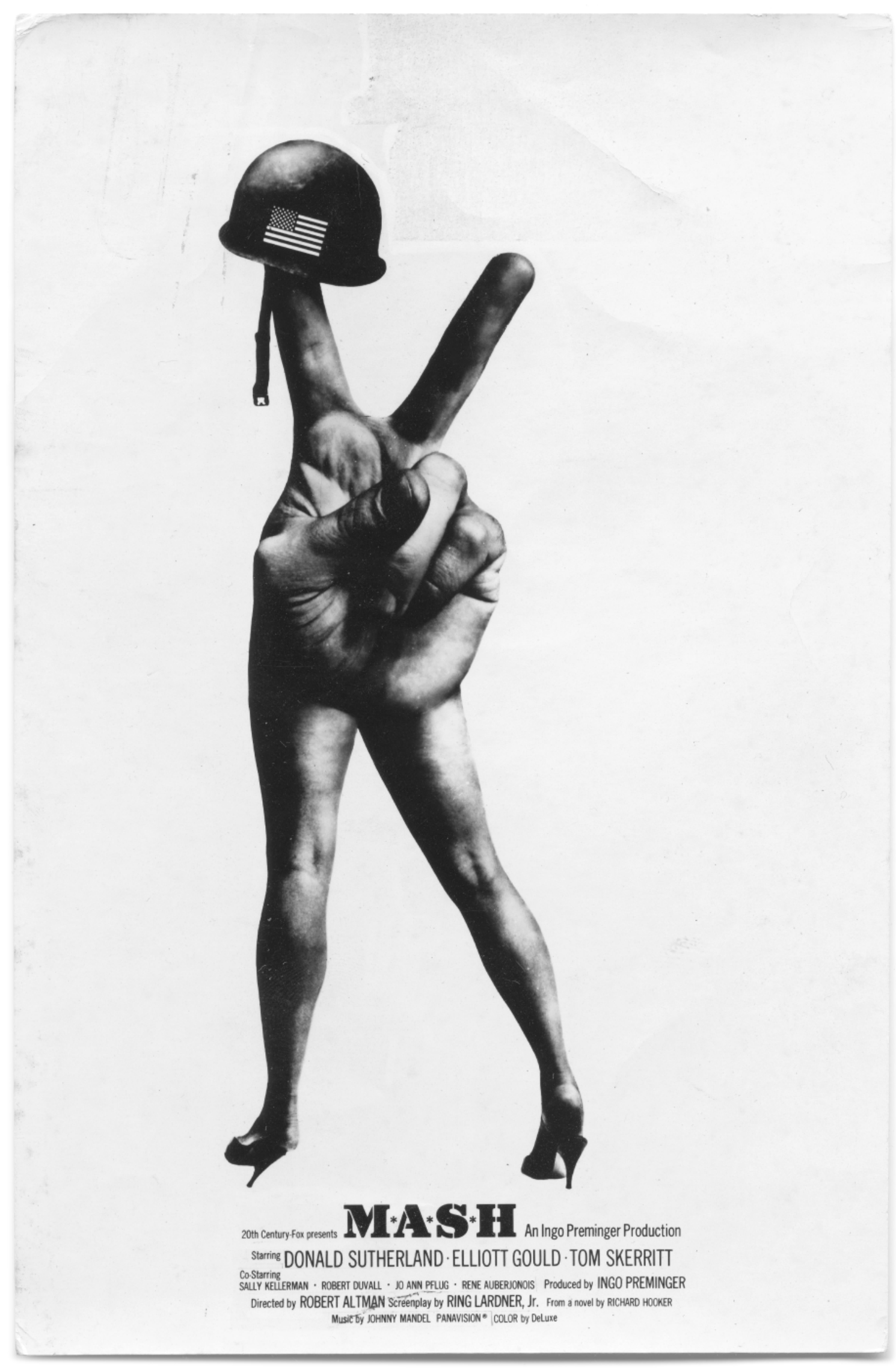




\section{ZATVARANJE KRUGA}

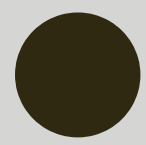

DOI: $10.31664 / z u .2020 .106 .12$

Svima koji su proživjeli uzbudljivo razdoblje društvenog oslobađanja na prijelazu šezdesetih u sedamdesete godine prošlog stoljeća ili su pak njegovi obožavatelji, u svijesti se kao ikona koja objedinjuje sav hedonizam, seksualno oslobađanje i sumornu zbilju Vijetnamskog rata usjekao kultni plakat filma M.A.S.H. Roberta Altmana. Malo nas je znalo da je autor tog najvećim svjetskim nagradama ovjenčanog plakata Splićanin Arsen Roje. Deset godina nakon umjetnikove smrti Galerija umjetnina u Splitu priredila je izložbu Zatvaranje kruga koja djelo Arsena Roje vraća u korpus hrvatskoga likovnog kruga. Poslije Splita izložba je predstavljena u riječkoj Galeriji Kortil i Galeriji Josip Račić u Zagrebu. Predstavljeni su crteži koje je Roje u maniri bliskoj estetici pop-arta bez premca na domaćoj likovnoj sceni 1965. i 1966. pred svoj odlazak u SAD izveo u Splitu, uz njegov posljednji ciklus slika s motivima dijelova ljudskog tijela izveden uljem na platnu na samom kraju života i karijere u Los Angelesu. O ovim ciklusima i svemu što je između njih predstavljalo profesionalnu karijeru Arsena Roje iscrpan i analitičan tekst za Život umjetnosti napisala je osoba koja je najbolje poznavala i umjetnika i njegovo djelo, njegova supruga, povjesničarka umjetnosti Jasenka Roje.
The poster for Robert Altman's movie M.A.S.H., 1970. The Courtesy of J. Roje.

\section{Branko Franceschi}

Moderna galerija, Zagreb 


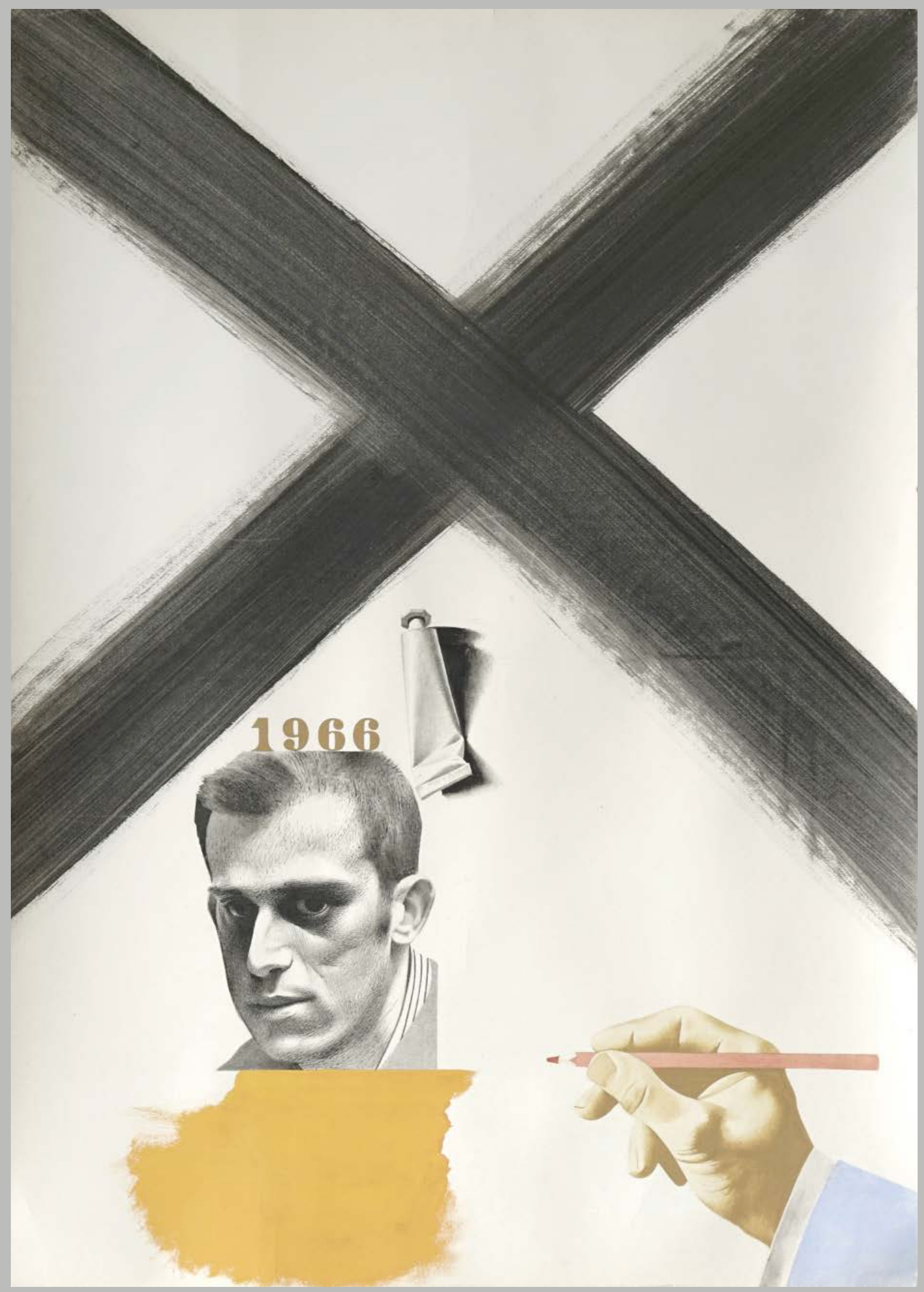

From the serial Drawings, 1965-1966, combined technique, paper, variable dimensions (Drawing with Selfportrait, I966). The Courtesy of J. Roje. 


\section{Arsen Roje's Artistic Development History}
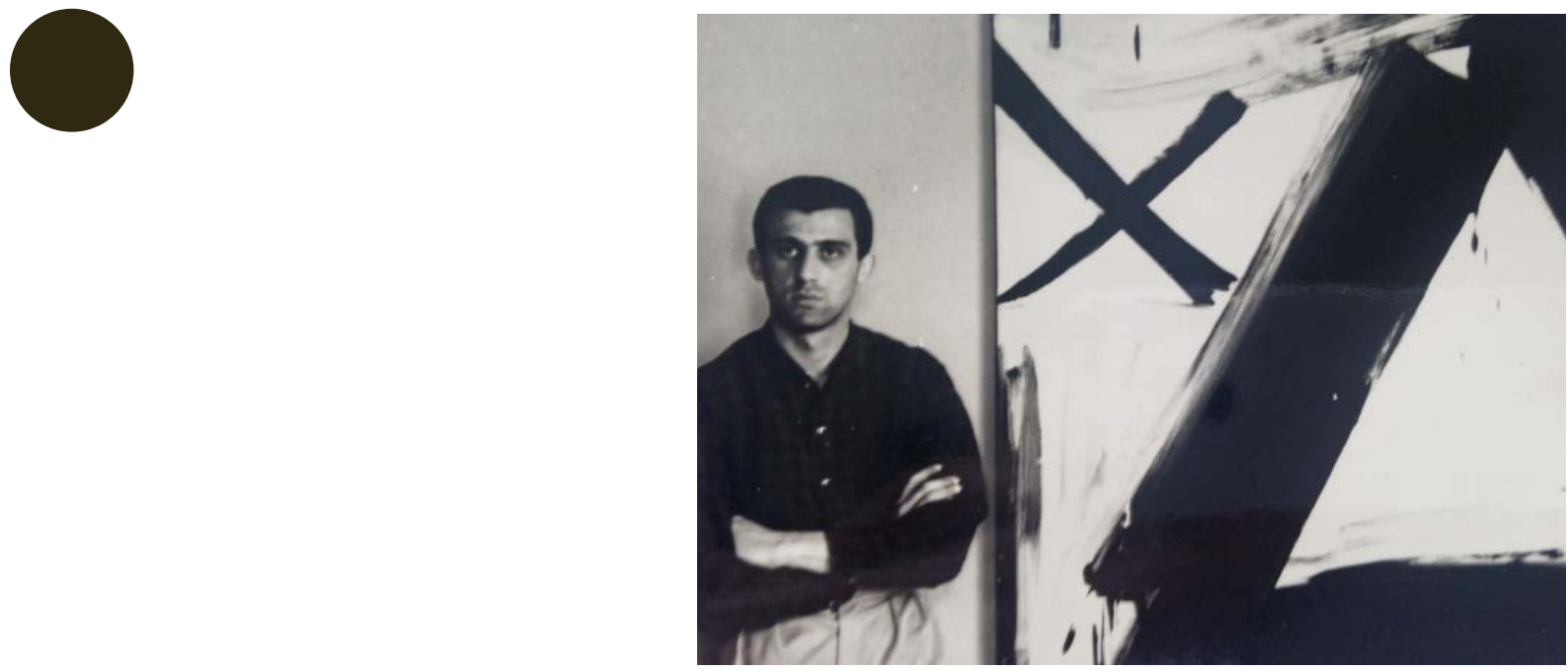

Arsen Roje was born with an exceptional talent that drove his life and took precedence over all other aspects of his personal and professional development. Even as an elementary school child, he agonized over an assignment of drawing a sheep since he wanted the sheep to be drawn with all of its plasticity and texture, something he never abandoned in his adult career as a painter. All else paled in his life except painting, as if painting was the very air he breathed. One could say that he lived to paint and that, in return, painting kept him going.

During his early formative years, however, Arsen was interested in sculpture rather than painting, inspired by a book on Michelangelo he received from his aunt in Italy. At that time, it was Michelangelo who aroused his interest in grand scale and the human body, while painting came later. In his teen, he did a sculpture of his grandfather's hand that still exists, a study that shared the melancholy romantic overtones of his favorite poet at the time, Leopardi. While studying sculpture at the Academy in Zagreb, he modeled an oversized self-portrait cast in plaster, possibly under the influence of German expressionism, of which only a photograph has remained after it was destroyed in a fire. There is also an existing portrait of Jasenka in plaster from the early sixties that was damaged, and a small sculpture of St. Jerome he did under the influence of Mestrovic for the cathedral of St. Duje in Split.

\section{Jasenka Roje}

Independent researcher, Los Angeles 
In the late fifties, in addition to modeling in clay, Arsen was furiously drawing hundreds of sketches of single figures on white writing paper, most of them in the style of Egon Schiele, all of which are now destroyed or lost. Training himself as a sculptor, his interest was on the human figure from the very start, and he often said during our early talks about art that he couldn't imagine painting an environment. He understood the human body, an already preexisting and timeless subject, studied its anatomy and made numerous drawings and sketches during his teens and early twenties. Even much later, when he fully committed to painting and almost completely neglected modeling except for an occasional object made directly in plaster, he never abandoned the body as his subject.

Arsen discovered painting in 1960, after receiving a couple of books from America, one on Pollock and the other on de Kooning. These books were a major discovery for the young Arsen because they represented his first opportunity to have a glance into the American art scene. De Kooning left an especially strong impression and, under his influence, Arsen made several rather large paintings that he later showed in 1964 at the short-lived Poreč Biennale, of which only three survived. Those paintings were bursting with color and youthful energy, and were almost all titled "I love you”. After seeing de Kooning, Arsen was eager to become an abstract artist and join the contemporary art scene, but this idea was short lived. He soon realized that new artists were arriving at the New York art scene, and he longed to go to America where original art was being made. However, since travel was restricted in I950s Yugoslavia, it was impossible to get a passport without having an American sponsorship, and finding an art dealer who would sponsor him remained a dream.

Since art doesn't belong to one person, but to the same generation of alike thinkers, Arsen felt ignored and misplaced in his own community for thinking differently and didn't find support either at home or at the Art Academy. Fascinated with everything American, he collected images that he found in the Yugoslav newspapers and occasionally in the Time or Look magazines, and in 1965/66 started a string of large drawings, akin to Pop Art, but not quite. In I966, he had not yet seen Lichtenstein's comic strip paintings nor Andy Warhol's Campbell Soup, but he was already inspired by popular imagery of the West that he used in combination with signs and lettering. Arsen envisioned these drawings as a hybrid between drawing and poster. They were delicately executed, with visually contrasting images where each drawing thematically contained an idea, as if made for an imaginary poster of an imagined movie. As a whole, they tell the story of a hopeful young artist's inner world as it was in I966, only months before leaving his native country and emigrating to the West.

In the drawing of an automobile accident, the idea is to contrast the death scene of the accident with a large red apple that may be interpreted as hope, as life continuing to exists, visually further accented by the juxtaposition of black ink and watercolor. In another drawing with a self-portrait, there is a large "X" looming over the subject's head, the " $X$ " suggesting something crossed out or denied. Both are drawn in black ink, thus visually composing a unit, while the yellow patch and the hand with a pencil are in color suggesting that art is a living part of the subject. In yet another drawing, there is a line of people seen in perspective going towards an airy arrow raising from the horizon, and we are inevitably forced to ask the question where these people are going, towards the sky, the unknown, or ultimately death? Occasionally, there is also absurdity and humor, as in the drawing Tea gone mad with a sketchy self-portrait as a cup of tea, and an actual hole perforating the paper next to the cup. This hole is interesting as it is evocative of "something missing", a recurring subject that will come up again in Arsen's late paintings as an erasure or cut of a part of the body.

Film was a subject that affected Arsen's life, first by coincidence and later by necessity. He was introduced to movie advertising in Paris, where he made a poster for Barefoot in the Park to escape working as a house painter. Coming to America

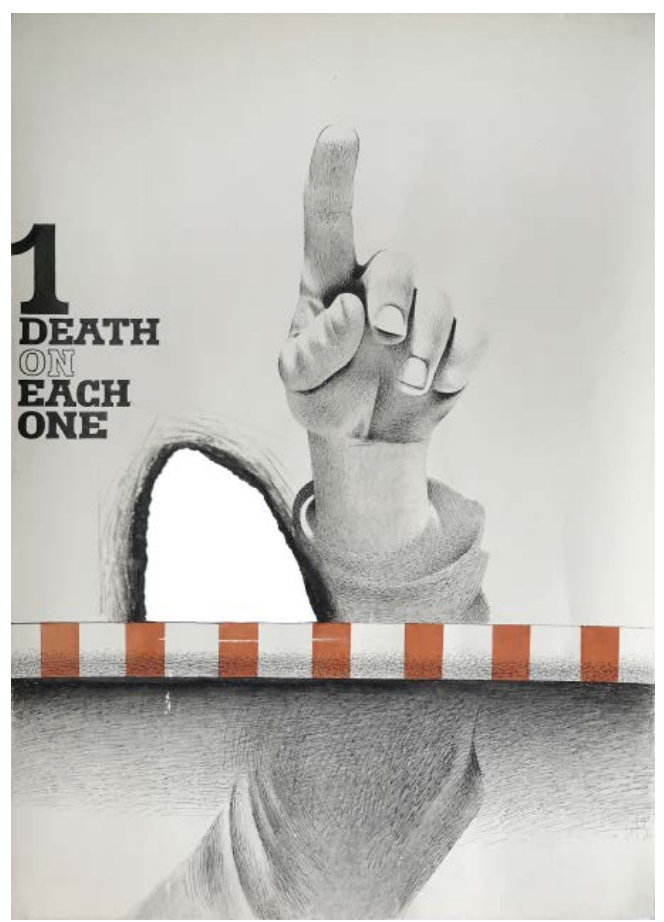

From the serial Drawings, 1965-1966, combined technique, paper, variable dimensions (Tea gone Mad). The Courtesy of J. Roje. 
initiated a period of personal and artistic confusion due to the too many impressions and learning opportunities that he was presented with. The 57th street in New York, where the galleries were located in 1968, was bursting with activity; you could still see and buy abstract expressionist paintings for a very reasonable price, Allan Kaprow was exhibiting a huge pile of automobile tires at the Whitney Museum, and Andy Warhol was making news with his "Factory". Being exposed to such artistic activity was mind blowing, but then reality set in. After walking the streets of New York looking for a job, rolling and unrolling a bundle of his drawings, necessity pushed Arsen again into movie advertising. His ideas were different from the illustrative style of the movie posters at that time, and he soon achieved fame in the industry with the poster for Altman's movie M.A.S.H. Part of the power and shock of the poster was in the way Arsen cut up the body and reassembled it, the upright sign of peace, the ideal, mirroring the base physicality of woman's legs, the real. Despite its success, Arsen remained ambivalent toward advertising, which was ultimately about selling a product regardless whether it was a can of soup or a great movie.

Passionately committed to art, Arsen experimented with many different styles and trends in the early seventies after leaving New York for Los Angeles. The city of Los Angeles was an alienating place without a center or human contact, with a landscape of cars moving through its arteries. Art was confined to few galleries on La Cienega Blvd. and the established movie studios were all-powerful. Among them was Universal Pictures, where Arsen freelanced for their advertising department after refusing the offer to take on Universal's complete yearly production. At that time, he did several paintings on large canvases in the style of his earlier drawings, albeit with more subdued subjects and a darker palette of grays painted with thinly diluted oil that he treated like ink or watercolor. He also did several smaller, black and white paintings in acrylic, some of which were textured and painted freely as drawings, all of them with humorous content. An example is a narrow vertical painting with a flaccid penis being pulled by a string, or another smaller painting with pairs of flies mating on a background of large white strokes that simulate flight, or one in color of a hand holding a cup and pouring red liquid into a shoe, with association to blood perhaps.

During the 70 -ies, Arsen painted numerous smaller paintings he later destroyed or painted over, some abstract, some figurative, but none he ultimately found satisfying. What was missing was the subject matter, and Arsen would literally hit his head against the wall in search of a subject to paint. As he continued to work for Universal Studios, he collected numerous promotional photographs from movies and decided to paint some of those images in large formats. The issue of the subject matter was not completely resolved, but nevertheless it was a subject he felt remotely connected to, not only through his work in movie advertising, but also because of his love of the language of movies and time spent in dark movie theaters during his youth when some of the best European movies could be seen in Split.

From an early age, Arsen showed no interest in painting landscapes, still life, or portraits with a sitting model, and all of his mature work was done from photographs. Once removed from the live model, he could study the model at a distance and this detachment allowed him to get involved and yet remain distant enough to treat the subject as a "picture", a pre-existing rather than a living subject. On the other hand, Arsen often cited van Dyck, who once said that his portraits need to "bleed if you cut it with a knife". Although not interested in painting a living model, it was important for Arsen to create the illusion of a real person who could "bleed if you cut it with a knife". This was the central tension in his life and work, this oscillation between the living and the pre-made.

Another issue that presented itself to Arsen when he started to paint after movie stills in the early 8o-ies, was how to paint a figurative scene in oil. Painting movie scenes on often very large canvases required mastery of the material, and for 


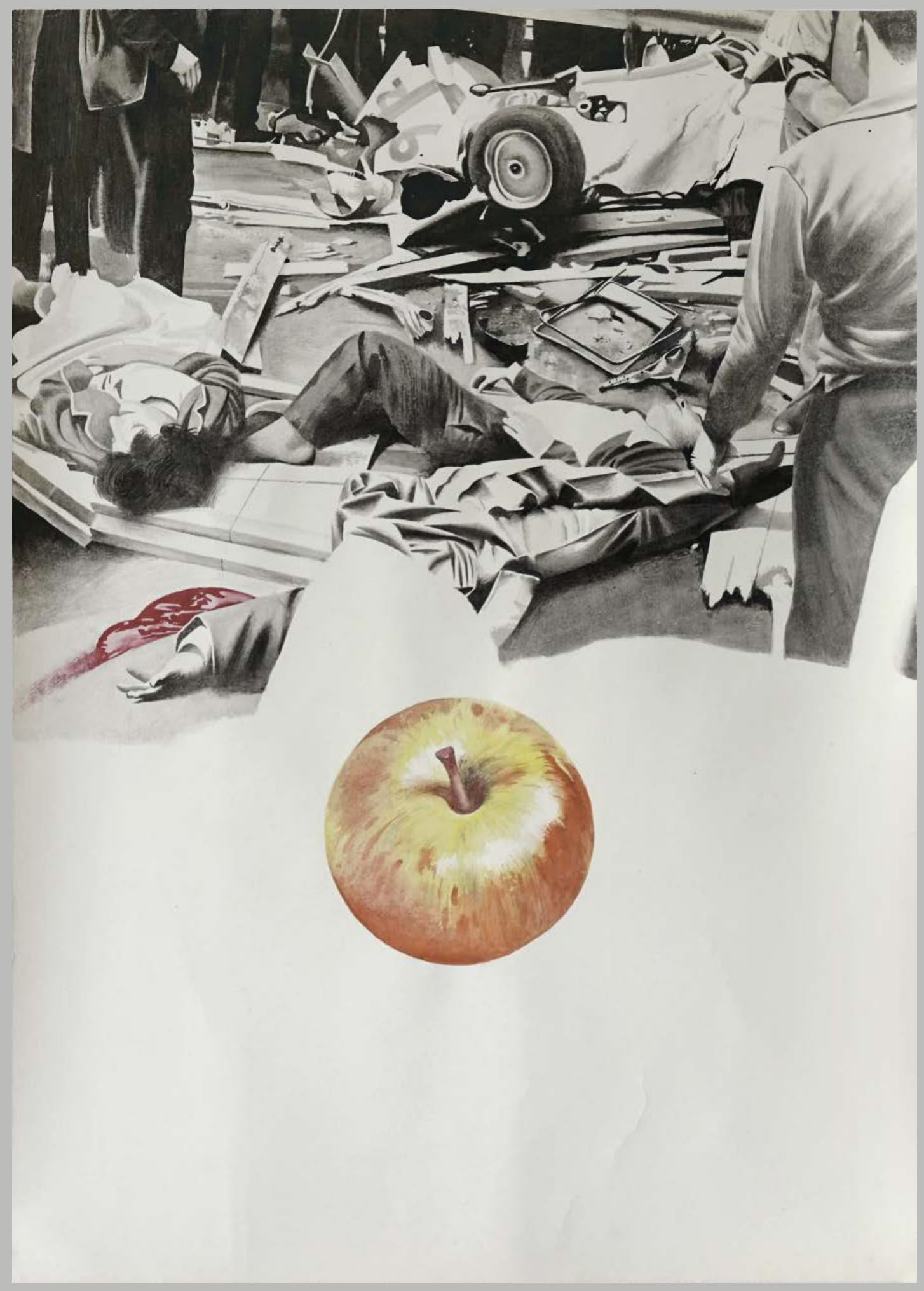




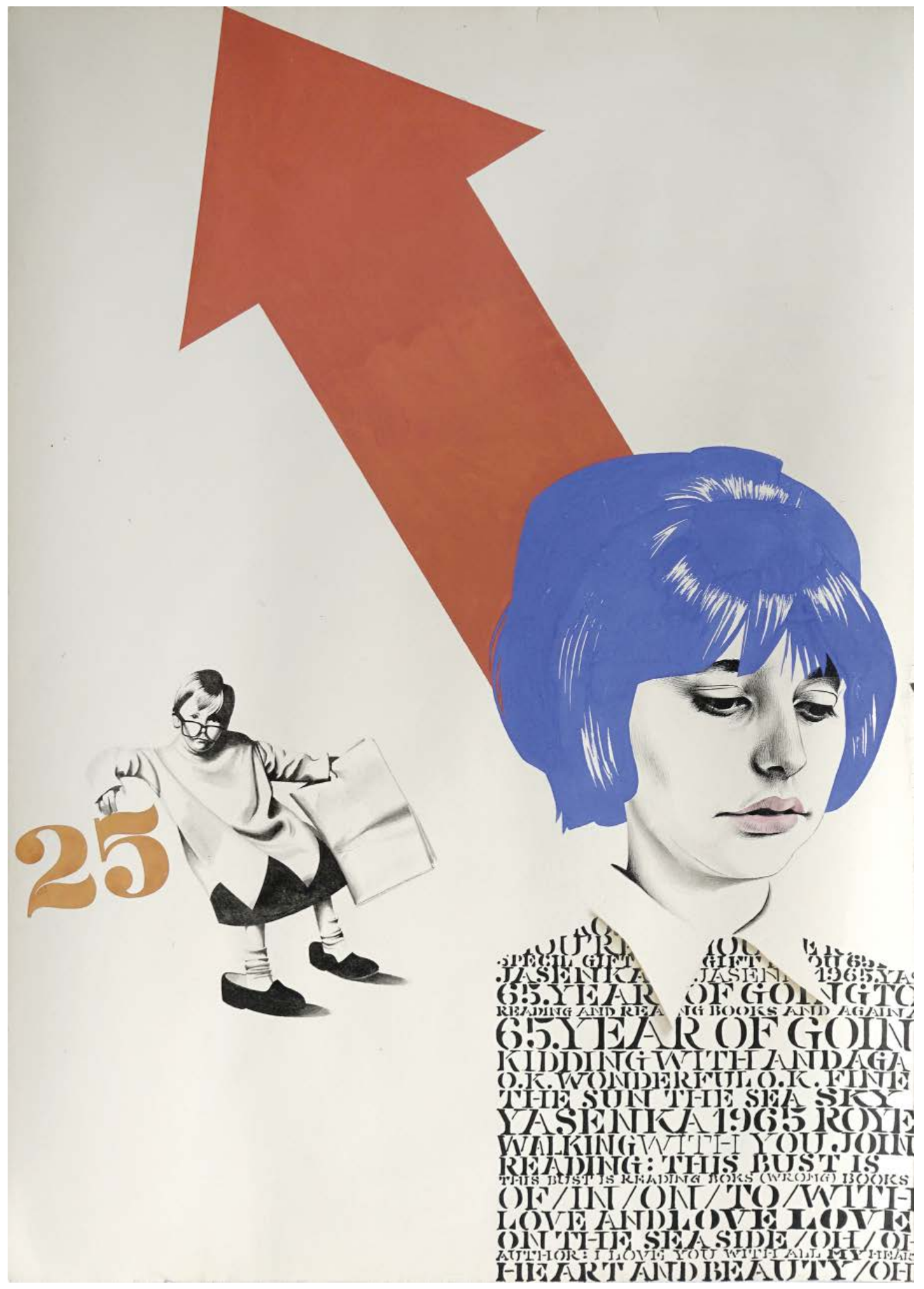


some time he practiced using different techniques and styles to learn the craft until, in 1985, had his first solo show at O.K. Harris in New York. In the I985 October issue of the Art Video, Ivan Karp gave an interview about the show, from which comes the following excerpt:
He is trying to establish that these images are a powerful iconic emblem. They are well known to the conscious, both conscious and subliminal. We recall these images, most of us do, and when we are re-confronted with them, we are reminded of them, here of course in rather remarkable scale. They are very large and in vivid aggressive color. We reintroduce images that we know well and re-experience them. In this sense it connects his art very closely to the Pop Art tradition, that is, using traditional imagery in curious ways.

During the 80-ies and early 9o-ies, these paintings were diverse in their approach because Arsen was not committed to any particular style and was playing with different styles and different techniques, sometimes with the focus on plasticity, sometimes on color, sometimes painting with lose brushwork and at other times tightening the brushwork to appear almost undiscernible from the form. He mostly painted in color that, together with plasticity, brought realism to a black and white photograph, but occasionally painted also in black and white to remain true to the movie. This was a decade long period of experimentation and learning that Arsen later called his true Academy, during which the paintings, some more and some less successful, continued to sell reasonably well.

One such example was Arsen's experimentation with color to create a sense of space and movement in the painting from 1984, Departure, depicting the final scene of the classic movie, Casablanca. This is a large painting, $891 / 2$ " $\times$ II5", with Bogart and Ingrid Bergman, the large size evocative of a movie screen. In the foreground are a French soldier and the actor Claude Rains, both somewhat larger than life-size, with Bogart behind them in the mid layer, and Ingrid Bergman and the actor who plays her husband further back. In the far distance, barely visible, are the lights of an airplane enveloped in fog. The scene is accentuated by two complementary colors, the green uniform of the French soldier on the left and the red car on the right, both seeming to enclose the scene from side to side and directing our focus to the main trio in the middle, the protagonists of the story who are intentionally painted in neutral beige that unifies them and thus thematically, as well as visually, forms what in the movie is a love triangle. Claude Rains in his dark blue uniform stands between the French soldier and the main trio, the blue of the uniform offering a visual bridge from green to beige and, at the same time, standing like a solid block between the soldier and the main group, which points to another aspect of the story, the actor's role as the intermediary between Bogart and the collaborating French army. Although the original movie was in black and white, the painting is in color. The brushwork of loosely stroked, mostly blue and gray color patches surrounding the figures, as well as the spatial layers between them, gives an atmospheric feeling to the scene, while the areas of rather solid color - green, blue, beige and red-stimulate the eye to follow their trajectory from one hue vibration to the next. This sensation again evokes film, a moving picture. Color here is a catalyst for the story, and visually generates movement in contrast to an otherwise static original photograph from which it was transferred to canvas. As it was a popular painting with Ivan Karp's collectors, there is another version of the same scene that was commissioned and promptly sold, as were numerous other works painted after movie stills.

What most of Arsen's paintings have in common is plasticity. This of course is an illusion, but it's worth mentioning because the issue of plasticity is a recurrent feature in Arsen's work, signaling back to his beginnings as a sculptor and years spent under the Mediterranean sun where objects are seen in sharply delineated forms. In a large painting from I992, a scene from the film noir, Maltese Falcon, Arsen's focus on plasticity is almost palpable. The size of the painting, 77 " $\times 99$ ", is such that the figures are approximately the size of a real person. The leading 
lady, in the role of the femme fatale, dressed in a mink coat, and Bogart in a suit and fedora as the detective, are facing another man in a heavy coat holding a gun, all of them in the foreground and extending vertically from top to bottom of the picture frame. The forth actor is sitting in a leather armchair, filling the space between them, and one has the impression that the figures could walk into real space due to an uncanny feeling of the overall physicality of the scene. With its skillful brushwork creating a sensation of almost virtual reality, this painting is already a precursor of Arsen's last series of paintings done between 2002-2007, in which plasticity of an organic form is emphasized to contrast a flat surface on which it is set.

In spite of the solid financial success of these works, Arsen subliminally understood that he couldn't fit into the American mainstream since he had never fully adopted the American and, by the same token, capitalist way of thinking that is driven by consumerism. As he used to joke, he could never understand baseball as he understood soccer.

From I990-2002, tired of painting from movie stills, Arsen made paintings by combining images from different sources into a unified scene as in Morning from I997, painted with tight brushwork and exhibited at O.K. Harris in I988. The figure of a man dressing in the foreground was added to the background scene where a woman in the bedroom appears as if having an argument with him. Earlier from that period are a couple of versions of Diver from I990, with much looser brushwork and heavier impasto where the figure of the diver is added to the background that may have been painted from memory.

Between 2000-2004, Arsen made a series of self-portraits looking at himself without mercy, as well as some portraits of his daughters and people he interacted with in the neighborhood, his Chinese car mechanic, his alcoholic photographer, an artist who lived across the street from the studio and a mentally ill man whom Arsen would often see on the street, quite an interesting mix of subjects, each of whom he found something in common with. At the end of that period, from approximately 1999-2002, he also made a series of oversized portraits and changed his style from the previous tight brushwork and plasticity to sweeping strokes of color covering the whole surface of the canvas. These were portraits, or rather heads, with tortured faces as if drowning in their own flesh, among them a portrait of his grandfather, Dedo, from 2002. This was Arsen's last show at O.K. Harris in 2002. None of the paintings were sold and most of them were later destroyed.

Arsen's true self, the self that we don't create in life through acquired identities, but the one that follows us from an early age, in spite of him was not fully absorbed by his American experience. It was as if he were driven through his life to get something that he knew didn't truly belong to him and, like that foreboding "X" over his head in the I965 drawing, he pushed and pushed to find his place in the American mainstream art until he was exhausted from pushing. Now in his sixties, he withdrew from the art world to again find that spirit that had been dormant for years, but was not lost.

In order to fully understand this last phase of Arsen's work, it is important to mention the influence of Samuel Beckett, the author of plays and seminal books that left a profound impact on modern literature. Beckett was a man with whom Arsen shared his own philosophical approach to life, as well as a recurring depression, and whose famous quote from the Unnamable - "You must go on. I can't go on. I will go on"- particularly resonated with Arsen's perception of his own life. It was Beckett's art of impoverishment, a human being reduced to a soliloquy, that helped him in his mature years to take off the pretense, all the unnecessary fluff of living, and reduce his subject to his own aging body.

The environment, which since his youth he never understood nor cared to paint, was the first thing Arsen eliminated in these late paintings. This was a moment of liberation from the requirements of figurative painting, liberation that had 
attracted him to sculpture in the first place. He could now devote all his energy to the body, an old subject he now began to cut and compose according to an idea. It is hard not to realize the violent aspect of cutting a body, although once removed from the live subject by the use of photography, the "mutilated part" becomes an aesthetic object in service of the idea, and in this context the body doesn't need to remain whole. On the contrary, it can be cut and positioned in whatever way the layout requires it. Arsen made hundreds of little thumbnail sketches where he noted ideas for paintings, but very few came to be actually painted and many were also painted over. It is interesting to note that using parts as well as erasures in stead of the whole body also had a psychological root in Arsen's work, a sense that part of his own body is missing or cut off. This was not a hallucinatory sensation, but an internal image of himself projected onto his body as missing something, not being whole. Cutting and erasing parts of the body can be observed in all of Arsen's late painting, as well as in some portraits, like the portrait of his daughter Dawn, in which a part of her face is obliterated with widely stroked purple paint. By the end, it was only his own body he mutilated and aestheticized, however.

In the beginning, Arsen painted backgrounds in uniform white or black oil, in two non-colors. The white was a composite of all colors, but not any color in particular, like an empty page of paper. Black was the absence of color, a nothingness, an invisible but nevertheless penetrable space. He also experimented with a couple of primary colors, but found that their potential for symbolism, pleasure and attention-grabbing could be overpowering, and didn't use them often. When he discovered automobile paint, an industrial material, it brought something new to the experience as it was impenetrable and excluded any pictorial space. It also pushed the painted subject into the foreground, onto the surface of the canvas. The champagne-colored automobile paint possessed metallic luminosity of a gold leaf that formed a powerful contrast to the organic form and transformed it into an aestheticized object. Arsen embraced it because it allowed him to make figurative painting into a painting of ideas, rather than living subjects. In the long run, automobile paint proved not to adhere well to the primed canvas and could easily chip off. Arsen tried other materials, like marine lacquer or oil-based house paint, which worked well but could not replace automobile paint. In some of his late paintings from 2005/6, he came back to the dark surfaces in oil, especially when addressing more personal and intimate themes, like in OOT or Right Hand, surfaces which were softer, more penetrable and more accepting of an organic form.

In terms of Arsen's iconography, fingers, hands, legs and feet were especially important subjects in his arsenal of imagery; single fingers as solitary units, phallic in shape and representing the male, hands as industrious parts of the body, often dirty with paint under their fingernails, which connected them to the craft of painting, and feet fated to perpetual walking, down to the ground, threading the world.

Among them were few paintings of single fingers on a black or colored surface that, due to their layout, seemed like portraits. These "portraits" could be witty, like Pinkie from 2005, with the little finger (called pinkie in English) on an also pink background, a play on the word pink, also referencing a gay man in the homophobic street vernacular. On the other hand, another, later painting-In blue, from 2005/6 - of a single index finger, stretched from the bottom to the top of the frame against a dark surface, evoking a sense of solitude and weariness. The position of the finger dominating the middle of the canvas from top to bottom may be an indication that the subject is a "standing figure" rather than a bust, and the blue ribbon that surrounds it and ends in a counter-clock motion at the finger's top left side creates an illusion that the figure is leaning towards the left as if weary or tired. The word 'figure' is used purposefully here instead of 'finger', as one tends to anthropomorphize the image and see the nail as the head and the rest of the finger as body. From the paint under the nail and the bulging knuckle bone, the viewer learns what it entails to be a painter, years of drawing and holding a pencil or brush, both self-referential details.

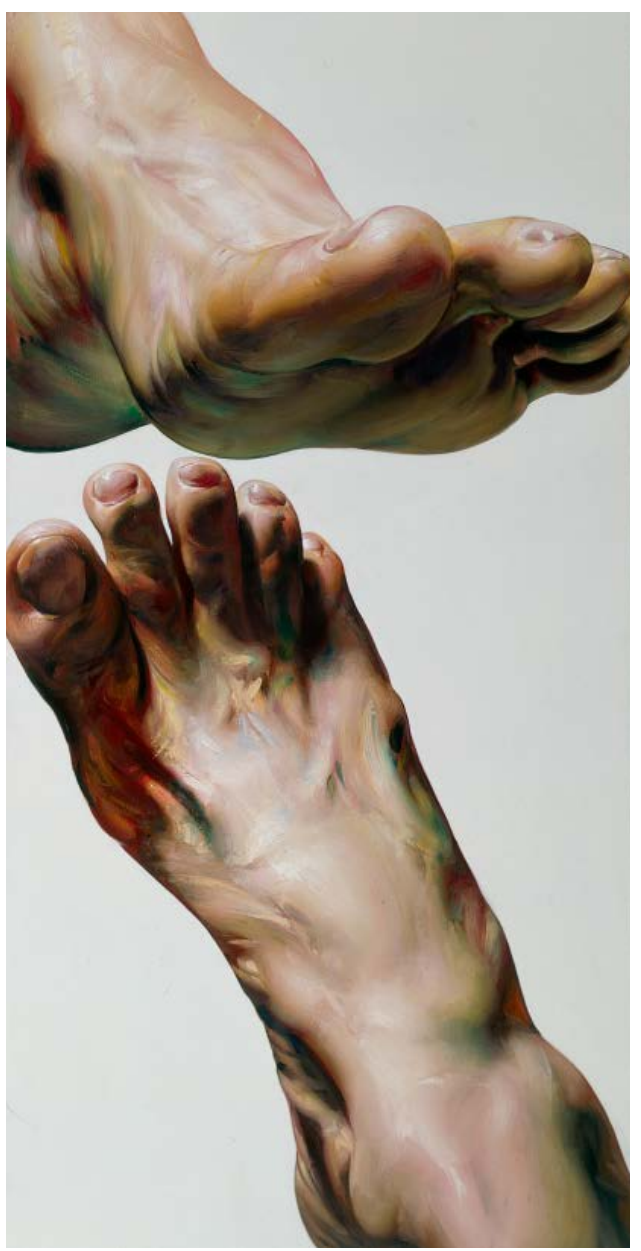

Walking Feet, 2003 , oil on canvas, $198 \times 99 \mathrm{~cm}$. The Courtesy of J. Roje $\uparrow$ 
Painting fingers as "portraits" has its root in kitsch, but Arsen liked to tackle kitsch by combining dissimilar styles, such as the juxtaposition of plasticity and "flatness" that he used in advertising, or substituting a fragment for the whole figure as in this "standing portrait" where a misplaced object, finger, is presented as a missing object, human figure, both coming from kitsch. Humor, absurd, banal and kitsch are frequent occurrences in Arsen's work, as are alternations in the overall tone of the painting, fluctuating between witty or playful and thoughtful or somber, like in the two paintings mentioned above.

Arsen's ideas often come from some personal experience or an image engraved in memory, like the humorous One and One Half from 2004, with two fingers standing next to one another as if posing for a "double portrait". One finger is half the size of the other, reminiscent of an old picture of Arsen as a small child, the half-a-man, and his father, the man. In yet another painting with automobile paint from 2005 , Hands, two arms cut horizontally across the canvas, one hand tightly holding onto the other while the other seems to be letting go of the hold. This simple gesture makes one think of holding onto something despite knowing that it's hopeless, in the same way one holds onto people, ideas, or life itself, knowing that time will obliterate it all. Another, similar painting with a fist partially appearing from the bottom of the frame-Coil, from 2005 likely self-referential, with its white knuckles suggesting a tight hold onto oneself, is a reminder of the Beckett's unarticulated "I" folding into oneself as if fearing that it may fall apart if it let go.

Feet were another subject Arsen frequently painted, such as in an early painting, the 2003 Walking Feet, of two large feet on a white surface, the OOT from 2005/6 that will be mentioned in another context, and a diptych of his own feet with the same title Feet from 2006. Walking Feet is an image of two of his wife's feet, photographed from different angles to create the effect that one foot, if it continued to move, would step on the other. This rather playful and amusing theme comes from a youthful memory of his wife, whom he often used to remind to look where she was going, a Proustian madeleine driving the positioning of the feet in the painting's layout. Feet, a small painting from 2006, is a much more somber painting with two feet next to each other and an actual small gap that separates them into a diptych. Seen from above, the feet take up almost the whole space of the canvas, with only small patches of black paint where their outline slightly curves, which creates a feeling of saturation and suffocation since there is nowhere to escape from one's own flesh. Choosing a diptych format is also interesting, since it separates the feet in the same way they come in real life, together yet separate. As previously mentioned, Arsen liked to play with words and ideas that he would then translate into visual language.

Not all of Arsen's paintings were painted after photographs of his own body. He frequently used pictures from magazines that he cut to get the desired layouts like the $Y$ from 2003, with woman's legs forming the letter "Y". In the simplicity of this witty play with the image and sign, the viewer can easily fail to notice that in the center of the "Y", where the foot of one leg presses at the knee of the other, there is a distinct patch of red paint above the big toe traveling down and appearing as a throbbing red spot of the foot, a small hub where pain and hurt are stored. This is a frequent feature in Arsen's work, a spot of redness to indicate something raw and hurtful, as in this painting where it contrasts with the appeal of a young woman's legs. As a side note, it also appears in another painting, Side effect from 2003, in which the painful area is similarly highlighted on the subject's back.

In another, much smaller painting - Caress, also from 2003-a fragment of a woman's face cut from a magazine is in color, while a large hand is painted in black and white. In the original picture from a magazine, this is the woman's own hand, but in Arsen's version it could be mistaken as someone else's hand placed on the woman's neck, partly because of the difference in color and partly because we cannot see where the hand is coming from. The stark contrast between the hand and 


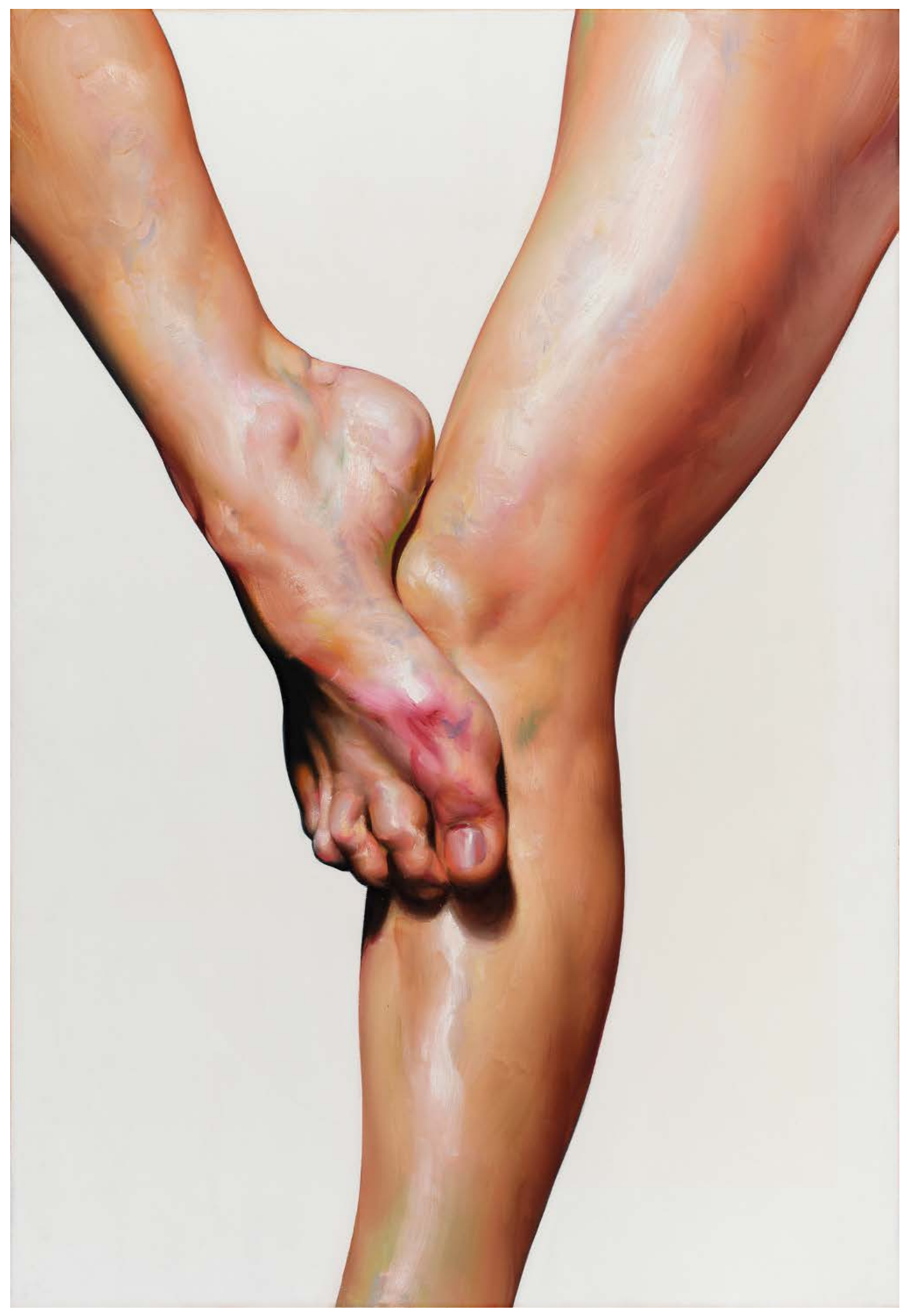

$Y$, oil on canvas, 2003 , oil on canvas, $198 \times 178 \mathrm{~cm}$.

The Courtesy of J. Roje.

$\uparrow$ 


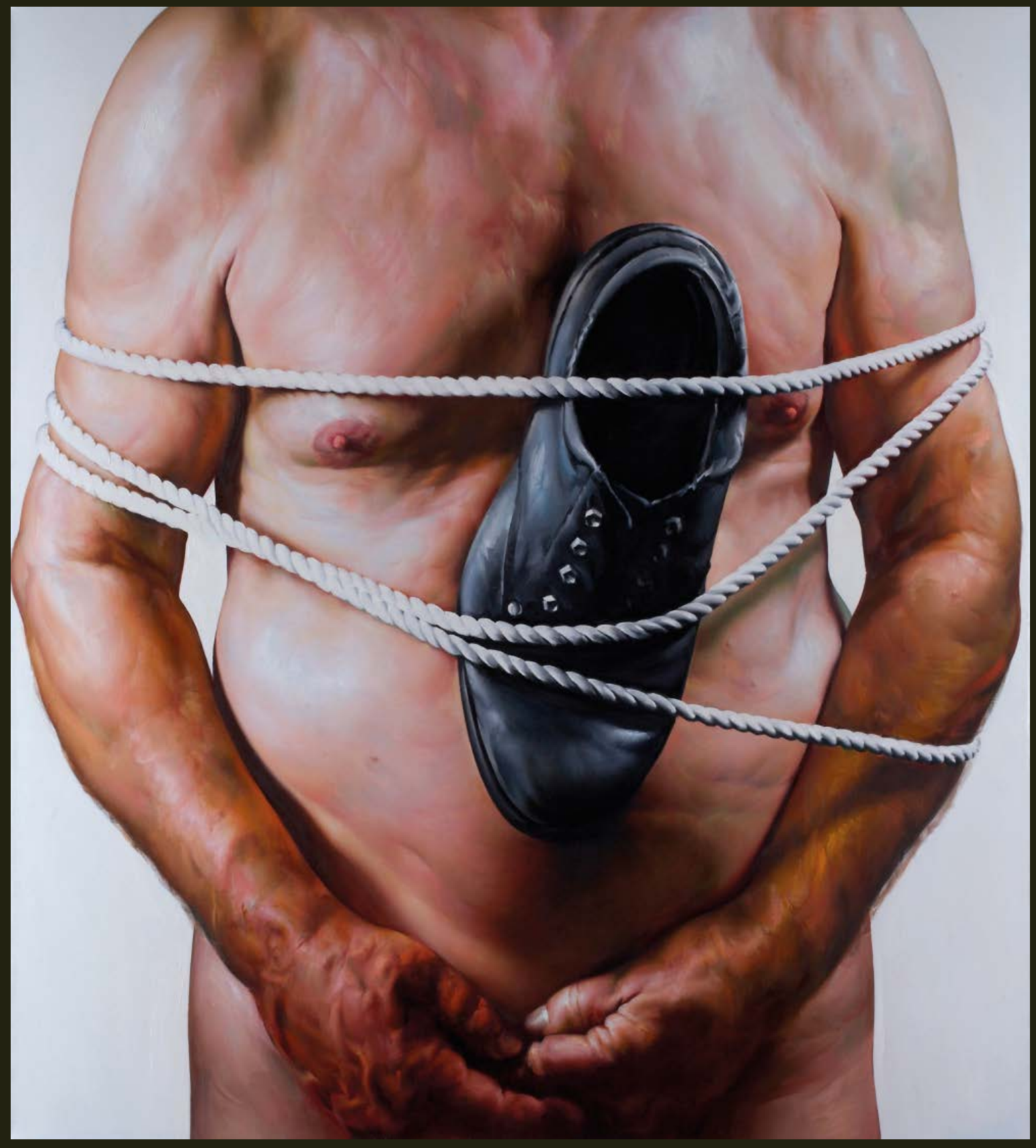


the neck and face leaves us with an uncomfortable feeling of possible danger. The woman's ear, compositionally placed right above the dark fingers, supports the feeling that she is listening and waiting in anticipation of something to happen.

There is also a small painting, Yes and No, from 2006, that Arsen cut from an earlier painting dating from 2004, and which shows two woman's legs in a crouching position and forming a pyramid-like shape with the knees on top of the pyramid. Such position of the legs, opening on the bottom but holding the knees tightly closed together on top, suggests the woman's dilemma whether or not to open her knees. The picture was actually taken from a porn magazine in which there was apparently no such dilemma, but the intent here was not to expose sexual imagery, only to hint at a sexual content and put the actual focus on a rather delicate decision, as the title suggests. The first version also included the torso of a naked model, which he later found unnecessary because it averted attention from the main idea, so he cut if off. There is only one existing painting, a picture from a magazine of a tightly executed and somewhat provocatively standing woman's nude on a white surface, but he has never repeated anything similar since.

Arsen often chopped up his paintings as if they were paper, the same way he cut images for movie advertising. He understood the language of advertising very well, which is quite apparent in the way he cut photographs to focus on some aspect of the image he wanted to put forward, or accented certain part of the image to expose its meaning, and there was always an inherent intent in the way he layed out and painted the image. Arsen believed that, if one could define art in one simple sentence, it would be that "art is everything except utilitarian", which was the reason why he couldn't be an advertising man. But he was an excellent designer and draftsman who learned from advertising the importance of eliminating everything that was not essential in order to expose the core idea, whether a witty play with image and word as in Pinkie, a deeply personal statement like the painting of his Right hand and OOT, or an absurd subject with a nod to Beckett like the Man with a shoe. All of his last paintings were rather tightly painted in order to achieve a photographic likeness, since the idea one wants to promote must be clear and not encumbered by any unnecessary clatter. This is an important point to make, and one that separates Arsen's work from figurative art painted after a live model, like the work of Lucian Freud for example. Arsen's method, borrowed from advertising, gave him freedom to play with multiple ideas, undeniably due to the influence of his American, rather than European experience.

What is also not unusual in Arsen's paintings is an idea behind the idea, a face or a title idea containing a concealed personal message that is not always obvious at first glance. An example are two paintings, the Man with a shoe from 2003, and the Measuring fat from the following year. The first, quite a large painting, presents the image of an aging man's torso with a black shoe tied onto his chest with white rope, an apparently absurd image. The man's black shoe is one of Arsen's favorite accessories that references the Father, while the rope literally suggests being bound by some obligation. In the child's imagination, the father is seen as coming into the private space of the home from the outside world, and the memory of it is visually compressed in the image of a black shoe. The overt and apparently absurd image averts the viewer's attention from the covert message embedded in the shaded hands of the model, which compositionally as well as literally create a barrier between the groin area and the rest of the body. This area of the body is painted in much darker hues that, seen from the child's perspective, put the emphasis on the hidden nature of parental sex, an idea behind the idea.

The second painting is of Arsen's own torso with two hands folding the flesh of the stomach in a banal gesture of measuring body fat. At first look, the title image distracts the viewer from noticing the intricacy of the two large hands, perhaps larger than life size due to the distortions of a photograph, that are the true subject of the painting. With their many fingers, nails, knuckles and protruding veins, these hands contrast in texture from the smooth and relatively uneventful skin of 
the torso. Because the image is cut in such a way that we see the hands coming in from the outside of the frame, they don't seem to be connected to the body and appear as two powerful, independent entities. This is how Arsen felt about his own hands, as essential and cherished part of his body for their ability to hold and manipulate the brush. In both paintings, the torsos are framed in such a way as to cover as much surface as the model's body could fill, in order to minimize the background and emphasize the figure as a container of the key idea inherent in the image.

Arsen used pictures of his own body, not out of vanity, but because they were familiar, the same way he held onto his old clothes because they felt like old friends. Painting his own body parts meant being with himself, looking at himself day after day alone in his studio, seeing his familiar and now aged hands, feet and legs as they lost their once youthful strength and power, but remained loyal companions throughout his life. The three paintings that he painted towards the very end of his life, Out no more, OOT, and Right Hand, are all large in scale and depict his legs, foot and hand respectively. They are somewhat different in content from the earlier paintings, as they paradoxically appear more intimate as they grow in scale since the large scale brings them closer to the observer.

In the autobiographical Out no more, from 2005, two legs are placed diagonally in an upside-down position over a dark green surface. The leg on the left is cut from the toe to the ankle and is diagonally positioned from the left corner down to the bottom of the frame, while the other leg, showing only the area around the knee, cuts the top corner on the right. It is immediately noticeable that these are the legs of an aging man, with pale flesh which hasn't seen the sun, as the title "out no more" suggests. The way the legs are cut appears to be quite violent, even more so because the legs are painted with such plasticity of skin, muscles and bones, and such hard realism that they appear almost real. Due to their diagonal and upside-down position, they also seem in motion, and the viewer feels as if witnessing the acrobatics of two withered legs against the dark screen. There is certainly irony and self-deprecating humor here, but the design alone is elegant, as in several other paintings, especially those with automobile paint, which tells of their aesthetic as well as realistic merit.

The other large size painting, OOT, from 2005/6, is painted from a photograph of Arsen's foot on a black surface, with only a small triangle of blue paint in the top right corner where the foot ends and the background begins, perhaps a piece of sky or someone coming up for air. The interesting feature in this painting is that the foot is violently cut along its right side, thus forming a straight vertical line where the flesh abruptly ends and joins the background. This points to the photographic nature of the image that could be cut at will, but it also denotes a more personal side, learning early in life that physical and emotional violence are a cultural norm and holding those wounds throughout his life. The ends of the toes are also partially missing, erased to allow the black paint to organically penetrate the flesh, another variation on the theme of missing parts. The foot itself is an organic form that cuts through the darkness of the black background, exposing its flesh under which one senses the bones and the intricacy of veins running through a living, pulsating body that is at the same time painfully intimate as well as monumental in its size. There is also some humor in this painting with regard to the missing part of the foot, and reflected in the title "oot" instead of "foot".

For a proper ending to this analysis of Arsen's work, one must discuss the third large painting with an monumental, yet intimate image of his right hand with the same title, Right Hand, from 2006. The large size of the hand tells not only of its importance as his "painting hand" but also of Arsen's early love for grand scale (his oversized self-portrait, for example), and the later influence of the large-scale paintings of American modern art. The large size allowed him to play with the brushwork that, from up close, looks almost abstract with its twists and turns of flesh-like colors from the dark areas of black and brown, to lighter tones of orange, 
peach, and white with an occasional stroke of green and blue. This painting depicts a simple image of his right hand, open fingers presented frontally and covering the whole area of the canvas with the fingers cut at the top and on the sides. The three visibly protruding bones coming from the bottom resemble branches holding the flesh and leading the eye upward towards the fingers that spread like a fan along the black surface. The painting, although simple in its presentation, is intricate in its description of flesh as it shows us the cracks on the surface, the intricacy of the swirling skin around the knuckles, and veins as they show up below the skin and then disappear and submerge. This seems like a simple picture of a hand with no reference other than to itself, mute in its reality, with no particular idea to express. However, one gets a feeling that, by its sheer scale, its presence overpowers its surroundings. Observed in a gallery against a living person, it seems like an intimidating presence, a familiar and yet unknown entity.

I would like to leave the reader with this image, as Arsen himself held both of those contradictory images at the same time, the familiar and the intimidating that he carried from his childhood into his adult life. Painting was a redeeming and vital force in his life, like the color in the drawing with a self-portrait from I966, or the light blue ribbon around the finger from 2006, or the humor that is repeatedly present in his work. Art preserved him from self-destruction, but his own words (he used to read or write while taking a break from painting), "I came to believe that destroying the painting is the only thing worth doing”, make us think that Arsen lived his life in perpetual conflict, one step away from the abyss, and that he carried it with him to the very end. 


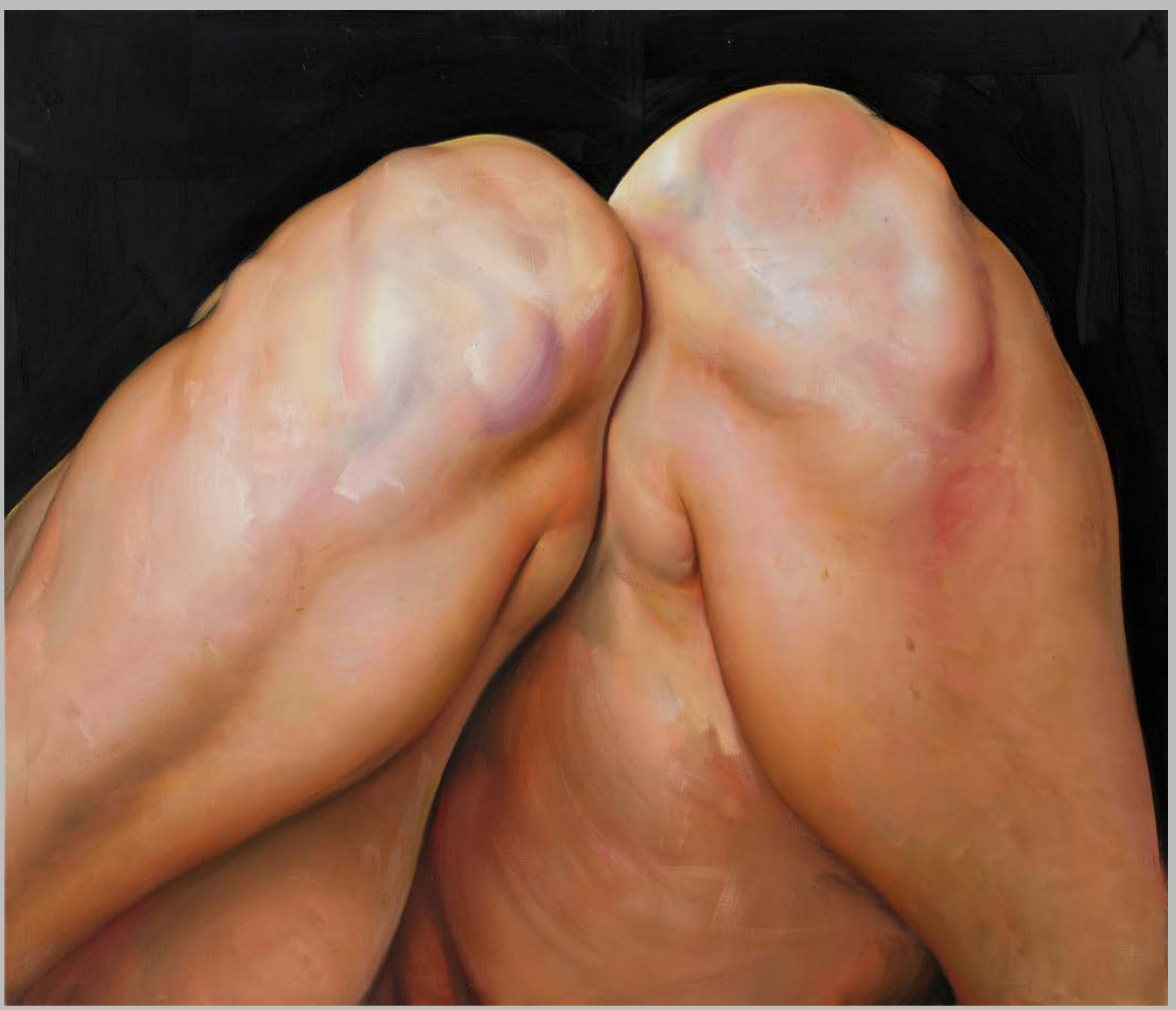

